\title{
LLANDOVERY MICROFOSSILS AND MICROFACIES OF THE HÝSKOV SECTION, PRAGUE BASIN
}

\author{
PETRA TONAROVÁ ${ }^{1, *}$, STANISLAVA VODRÁŽKOVÁ ${ }^{1}$, OLLE HINTS², PEEP MÄNNIK², MICHAL KUBAJKO', \\ JIŘ́ FRÝDA ${ }^{1}$
}

\author{
${ }^{1}$ Czech Geological Survey, Klárov 3, 11821 Prague 1, the Czech Republic; e-mail: petra.tonarova@geology.cz, \\ stanislava.vodrazkova@geology.cz,michal.kubajko@geology.cz,jiri.fryda@geology.cz. \\ 22Department of Geology, Tallinn University of Technology, Ehitajate tee 5, 19086 Tallinn, Estonia; e-mail: olle.hints@taltech.ee, \\ peep.mannik@taltech.ee.
}

* corresponding author

Tonarová, P., Vodrážková, S., Hints, O., Männik, P., Kubajko, M., Frýda, J. (2019): Llandovery microfossils and microfacies of the Hýskov section, Prague Basin. - Fossil Imprint, 75(1): 25-43, Praha. ISSN 2533-4050 (print), ISSN 2533-4069 (on-line).

\begin{abstract}
The lower Silurian strata of the Prague Basin, as well as in many other regions, are primarily represented by black shales, with limited to no record of benthic life. In this paper, we describe an exceptional late Aeronian volcanic-carbonate succession from the Hýskov locality near Beroun, which contains a diverse and well-preserved fossil assemblage and specific microfacies features. The studied section is mostly represented by well-washed, poorly sorted skeletal grainstones, rudstones and floatstones along with volcaniclastic material. The environment is interpreted as agitated, above storm wave base, and with rapid sedimentation and burial. The collection of acid-resistant microfossils includes abundant scolecodonts, conodonts and chitinozoans, of which only the chitinozoans have previously been studied. The scolecodonts recovered represent at least 14 polychaete genera and 20 species. The fauna bears a great similarity to the early Silurian assemblages previously reported from Baltica, and some environmentally sensitive species allow constraining the assemblage to shallow-shelf settings. The recovered conodonts similarly show close affinities to Baltic faunas, and suggest a Rhuddanian - Aeronian age for the studied section. The chitinozoan assemblage, containing at least eight species, is dominated by Conochitina, and most likely belongs to the $C$. alargada Biozone.
\end{abstract}

Key words: Prague Basin, Silurian, Želkovice Formation, microfacies analysis, scolecodonts, polychaete jaws, conodonts, chitinozoans

Received: February 13, 2019 | Accepted: May 22, 2019 | Issued: August 29, 2019

\section{Introduction}

The early Silurian sea of northern peri-Gondwana was mostly anoxic, or strongly dysoxic, with black shales being typical sediments in many regions. This is also true in the Prague Basin, Perunica, where graptolite-bearing black shales are the dominant facies in the lower Silurian succession. The view of the Llandovery environment as anoxic and devoid of benthic life changed after the discovery of volcanic-carbonate facies in the Želkovice Formation, between the villages of Železná and Hýskov near Beroun (Havlíček and Kříž 1973). Richly diverse, thriving benthic and planktonic assemblages have been described from this locality; also unique in the context of the Llandovery in northern peri-Gondwanan regions (Štorch 2001). Graptolite finds showed that stratigraphically the succession belongs to the lower part of the Stimulograptus sedgwickii Biozone (Štorch 2001), thus corresponding to the late Aeronian carbon isotope event interval (Frýda and Štorch 2014) and to a globally traced sea level fall (Loydell 1998). Due to the latter, hiatuses in many shallow shelf areas are known worldwide, limiting the information available on benthic faunas from this time interval.

The fossiliferous volcanic-carbonate facies in the Želkovice Formation provides an opportunity to fill in this gap. Microfossils from the Hýskov locality were previously studied by Dufka $(1990,1992)$, who reported the occurrence of acritarchs, chitinozoans, prasinophycaean algae, scolecodonts, and conodonts; but only the first two groups have been studied in greater depth. According to Dufka (1990), the Hýskov acritarch assemblage is diverse and well preserved, indicative of low thermal maturity. Seventy-five acritarch species were recovered; 17 of them also occur in Norway, and a limited number in Wales (Dufka 1990 and references therein). Dufka (1992) further 


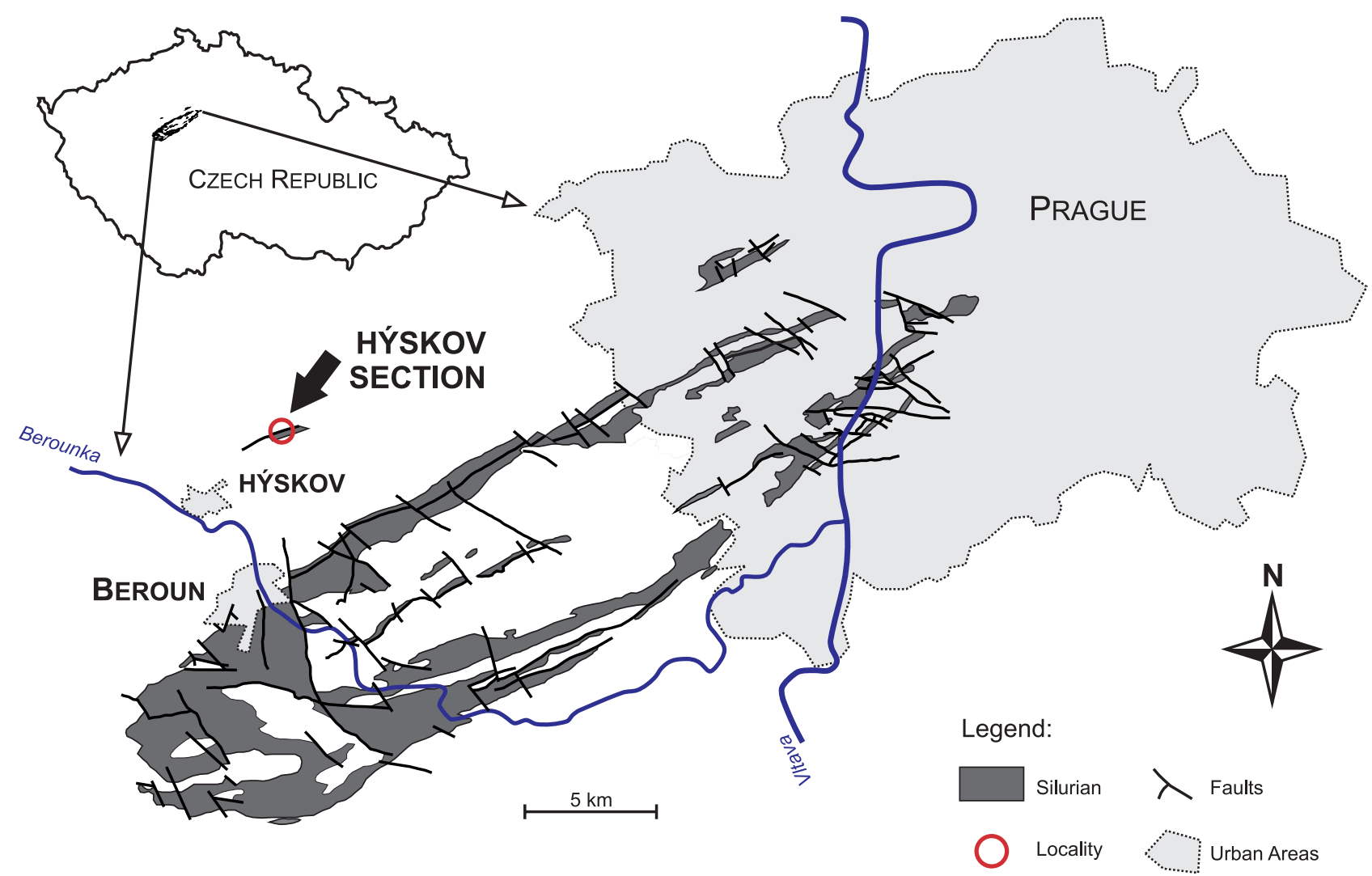

Text-fig. 1. Locality map of the Prague Basin and the Hýskov section. Redrawn after Havlíček and Štorch (1990: fig. 6).

reported the occurrence of five species of chitinozoans from Hýskov, including Conochitina iklaensis and Conochitina emmastensis, which were previously known from Baltica, China, and the Brabant Massif (Dufka 1992 and references therein).

In the present paper, we document microfossils and microfacies of the Želkovice Formation based on a new excavation from 2017 as well as previous pilot samples from the Hýskov locality (Text-figs 1,2). Our initial target was to recover and study scolecodonts (polychaete jaws), which are virtually unknown from the lower Silurian of the Prague Basin thus far. However, the accompanying conodonts and chitinozoans provided further biostratigraphic and biogeographic constraints for the Hýskov succession. Additionally, the depositional environment was studied using microfacies analysis in order to provide a palaeoenvironmental background for the microfossil assemblages.

\section{Geological settings}

The Prague Basin is a classical geological area composed of only slightly metamorphosed Lower Palaeozoic rocks, and containing common fossils that have been studied for more than 150 years (see Chlupáč et al. 1998 for review). The Silurian sequence of the Prague Basin is relatively complete, with rocks from the earliest Llandovery to latest Př́idolí age.

The Silurian Želkovice Formation conformably overlies sandstones and shales of the latest Ordovician Kosov Formation, and is typically represented by very fine claystones with black silty shales, siliceous shales, and silicites (Křŕž
1975, Štorch 1986). The fossil assemblages of the Želkovice Formation are typically planktic and epiplanktic, but benthic

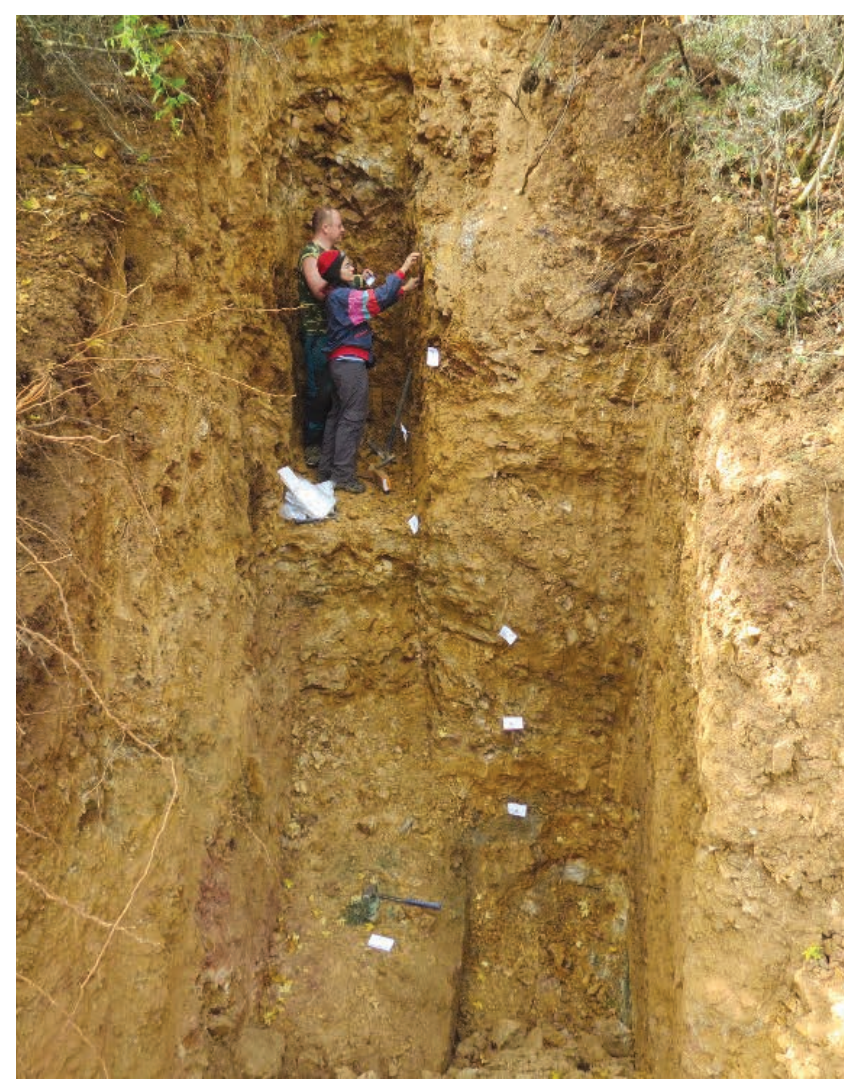

Text-fig. 2. Photograph of the newly opened pit for sampling, between the villages Hýskov and Železná. 


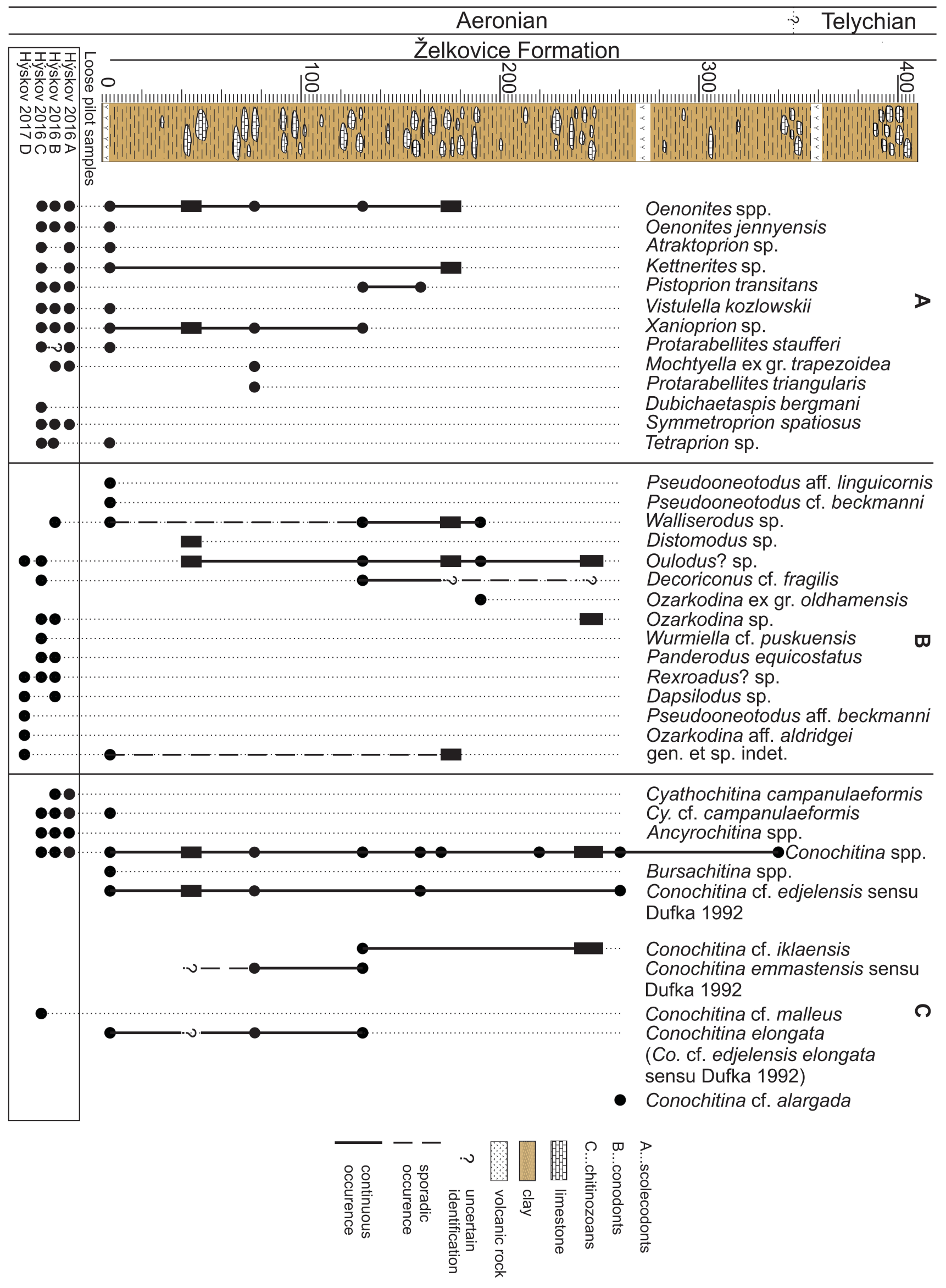

Text-fig. 3. Combined section log showing the main fossil groups, microfacies features and distribution of microfossils in the Hýskov section. 
elements are practically absent (Bouček 1957, Kř́iž 1991). The Hýskov volcanic-carbonate facies corresponding to the upper part of the Želkovice Formation is limited to a large tectonic block preserved in a tectonized zone along the Prague Fault zone. In the 1970s several excavations were dug, with the sections numbered DB 217, 222, 223 and 226; with DB 217 and 226 representing the lower part, DB 223 the middle part and DB 222 representing the uppermost part of the sequence (Šnajdr 1978, Štorch 2001). The following groups were collected and studied taxonomically: brachiopods (Havlíček 1977, Havlíček and Štorch 1990), trilobites (Šnajdr 1978), dendroid graptolites (Kraft 1982), acritarchs (Dufka 1990), chitinozoans (Dufka 1992), and graptoloid graptolites (Štorch 2001).

The succession is composed of doleritic basalts, tuffs, tuffaceous shales, and tuffaceous laminated limestones that contain a rich graptolite fauna including Stimulograptus sedgwickii and Neolagarograptus tenuis, confining the Hýskov succession to the lower part of the sedgwickii Zone (Havlíček and Kříž 1973, Štorch 2001). The depositional environment was described by Kř́ž (1991) as wellventilated shallow-water flats with favorable conditions for immigration and development of benthic communities, which formed on accumulations of volcaniclastic sediments as well as intrusive and effusive basalts produced by the Hýskov Volcanic Center. Šnajdr (1978), who studied trilobite assemblages from Hýskov, suggested agitated sedimentation and redeposition. Based on the palynofacies, Dufka (1990) interpreted the environment as oxygenated, rich in nutrients, and situated further offshore due to the scarcity of landderived microfossils. Interpretation of the depositional settings was further elaborated by Štorch (2001), who provided a detailed description of the sedimentary record, fossil content, and taxonomic assessment of graptolite assemblages from the re-opened and extended test-pits DB 222, 223, and 226. Storch (2001: 61) interpreted the environment as "sub-normally to normally oxygenated, mid-higher photic zone, influenced by both wave and current activity". According to the latter author, the shallowwater sedimentation at Hýskov was not only influenced by the growth of the local submarine volcano, but also by the simultaneous eustatic sea-level fall, which was recorded in the lower sedgwickii Zone (e.g. Johnson 1996, Loydell 1998), and which could account for the appearance of faunal elements (with British-Scandinavian and Baltic affinity) recorded among trilobite, dendroid, brachiopod, acritarch and chitinozoan communities in the Hýskov succession (Šnajdr 1978, Kraft 1982, Havlíček and Štorch 1990, Dufka 1990, 1992).

\section{Material and methods}

Thirteen samples from the newly opened pit $\left(50^{\circ} 0^{\prime} 11.160^{\prime \prime} \mathrm{N}, 14^{\circ} 4^{\prime} 10.980^{\prime \prime} \mathrm{E}\right.$; Text-fig. 2) and three samples from older excavations $\left(50^{\circ} 0^{\prime} 13.884^{\prime \prime} \mathrm{N}\right.$, $\left.14^{\circ} 4^{\prime} 10.667^{\prime \prime} \mathrm{E}\right)$ were collected and processed for the extraction of microfossils. The samples, 250 to $950 \mathrm{~g}$ in size, were dissolved using acetic acid (6\%); and in some cases hydrofluoric acid was used (for those samples with a greater volcaniclastic content). The residues were washed through a 50-micron sieve, the microfossils were hand-picked from the residues and stored in small plastic containers. The specimens were documented using a Tescan Mira 3GMU scanning electron microscope at the Czech Geological Survey in Prague. All samples and individual specimens are housed in the collections of that same institution (under collection numbers PT82 to PT97).

A microfacies analysis was carried out on 29 thin sections of $45 \times 27$ and $45 \times 55 \mathrm{~mm}$ formats, using Carl Zeiss Stemi 2000C and Nikon Eclipse E600 microscopes, the latter was equipped with a Nikon DS-Fil camera for imaging. The FEG-SEM Tescan Mira 3GMU scanning electron microscope, fitted with an Oxford Instruments EDS SDD X-Max $80 \mathrm{~mm}^{2}$ analyzer, was used to investigate in detail the polished thin sections. The analytical conditions used were $15 \mathrm{kV}$ accelerating voltage, $1.5 \mathrm{nA}$ beam current, and $15 \mathrm{~mm}$ working distance. A BSE detector was used for imaging.

A preliminary whole rock X-ray diffractometric analysis was carried out on a sample from the 260-280 cm level.

\section{Microfacies analysis}

The new excavation exposed $4 \mathrm{~m}$ of a strongly tectonized section; the limestone beds were fissured and dislocated, existing at present as limestone lenses embedded within highly tectonized clay (Text-fig. 3). Due to insufficient exposure and high tectonization, field observations of the sedimentary structures were not possible; therefore, only microfacies criteria were used for the interpretation of the depositional settings.

Text-fig. 4. (a) Tuffaceous wackestone with thin skeletal laminae formed mostly of trilobite exoskeletons and brachiopod shells. Base of the section. (b) Poorly sorted skeletal grainstone with echinoderm ossicles and sponge spicules as the main components. Volcanic glass forms the matrix of the rock as well as geopetal infills. Interval $\mathbf{4 0 - 5 0} \mathrm{cm}$ above the base of the section. (c) Poorly sorted grainstone with glass shards matrix and fragmentary preserved bioclasts represented by crinoid ossicles, sponge spicules, and cryptostomate bryozoans. $130 \mathrm{~cm}$ above the base of the section. (d) Example of spar-filled voids in poorly sorted skeletal floatstone with a grainstone matrix, and tabule coral fragment, sponge spicules, ostracods, trilobite exoskeleton and crinoid ossicles. Note the occurrence of sponge spicules randomly distributed within the irregular spar-filled void, which could have formed after the decay of soft sponge tissue. 160 $\mathrm{cm}$ above the base of the section. (e) Laminated grainstone showing the interlayering of fine-grained layers formed by volcanic glass with coarser-grained skeletal accumulations. Interval $170-180 \mathrm{~cm}$ above the base of the section. (f) Poorly sorted skeletal floatstone with grainstone matrix formed by volcanic glass shards. The main components shown are rugose coral fragments, sponge spicules and altered volcanic glass. Note the spar filling cavities in the volcanic glass matrix. $185 \mathrm{~cm}$ above base of the section. (g) Poorly sorted bioclastic floatstone with grainstone matrix formed by volcanic glass. Skeletal components shown are brachiopod shells, trepostomate bryozoans, and crinoid ossicles. The volcanic glass shows various degrees of alteration. $240-255 \mathrm{~cm}$ above base of the section. (h) Laminated, silicified tuffaceous shale. Interval $260-280 \mathrm{~cm}$ above the base of the section. 

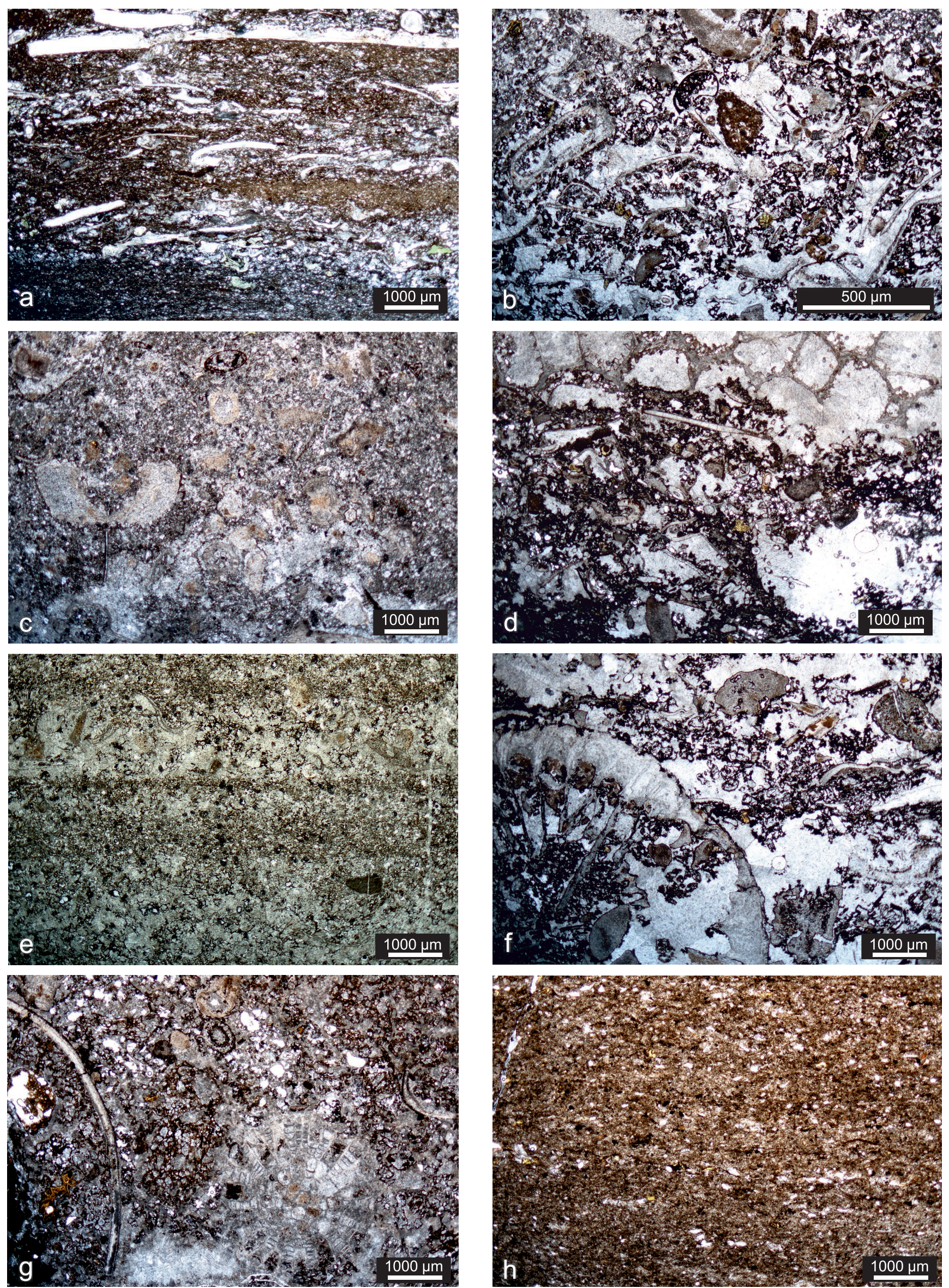


\section{Interval 0-20 cm: Tuffaceous mudstone-wackestone with skeletal packstone laminae (Text-fig. 4a)}

The succession starts with greenish, tuffaceous mudstones and wackestones, with fragmentary preserved and poorly sorted bioclasts up to $1.5 \mathrm{~cm}$ in size (brachiopods, trilobites; and subordinately also trepostomate bryozoans and rugose corals), along with glass shards of ca. $200 \mu \mathrm{m}$ in size as well as devitrified volcanic glass. Bioclasts are partly silicified - with silicified rims formed by microcrystalline quartz, in certain cases showing microborings; but no micritic rims were observed. Skeletal concentrations form layers a few millimeters thick in a laminated tuffaceous, argillaceous matrix; the matrix lamination and shell layers are disrupted by bioturbation. The alternation of higher-energy, poorly sorted skeletal accumulations with current-oriented shells of brachiopods and trilobites as well as a low-energy laminated argillaceous, tuffaceous matrix is suggestive of more distal tempestite facies.

\section{Interval 40-255 cm: Poorly-moderately sorted skeletal grainstone/rudstone/floatstone with moderately well- -sorted glass shards matrix (Text-figs $4 b-g, 5 d-f$ )}

In the lower part of the interval $(40-90 \mathrm{~cm})$ the deposition of poorly sorted skeletal grainstone with a moderately wellsorted glass shard matrix took place (Text-figs 4b, 5d). Fossil content is high, ranging from 10-30\%. Bioclasts up to $1.5 \mathrm{~cm}$ in size are formed by fragmentary preserved crinoid ossicles (dominant), abundant sponge spicules as well as ostracods, common brachiopods, gastropods; and subordinately, trilobites, bryozoans, and abraded fragments of calcareous green algae. Skeletal accumulations are nongraded, forming ca. $1.5 \mathrm{~cm}$ thick layers, which are strongly disturbed by bioturbation.

Higher up in the section $(95-130 \mathrm{~cm})$ grainstones are moderately to poorly sorted and finer-grained, with thinner layers of skeletal accumulations, primarily formed by the remains of thin-shelled brachiopods, ostracods, echinoderms, and sponge spicules (Text-figs 4c, 5e, f). Several episodes of shell accumulation were recorded, with the horizontal orientation of elongated shell fragments suggestive of current transport.

The sample from the $160 \mathrm{~cm}$ level is represented by coarse-grained, poorly sorted floatstone with a grainstone matrix along with large brachiopod shell and echinoderm remains, large tabulate coral fragments, sponge spicules, ostracods, rare fragments of calcareous green algae, and several voids filled with sparite (Text-fig. 4d).

The shallowing-up sequence is terminated by a laminated, finer-grained, and moderately well sorted skeletal grainstones (Text-fig. 4e). The lamination is formed by the alteration of layers composed of non-graded skeletal accumulations, with a fine-grained matrix formed by glass shards and shell hash. Better sorting, the smaller size of the bioclasts, and lower rates of bioturbation are suggestive of a more distal deposition in comparison to the previous facies, but still with energy levels high enough to prevent the deposition of micrite. A later shallowing pulse was recorded in the 185-255 $\mathrm{cm}$ interval, represented by the deposition of poorly sorted skeletal rudstone and floatstone, with a grainstone matrix and fragmentary preserved echinoderms (dominant), abundant sponge spicules, brachiopods, ostracods, gastropods, rare bryozoans, rugose corals, trilobites, rounded tuffaceous intraclasts, and abraded fragments of calcareous green algae (Text-fig. 4f, g). A rather rapid accumulation is suggested due to the preservation mode of larger brachiopod shells (not crushed, but articulated) as well as the frequent occurrence of umbrella-sheltering zones filled with sparite.

In general, within the $40-250 \mathrm{~cm}$ interval, bioclasts show bioerosion (microborings) to a certain extent; but no micritization nor peloid formation was observed. All bioclasts are silicified, no selective silicification was recorded. Iron oxides are disseminated within the sediment and also commonly occur as a grain coating.

\section{Interval 260-280 cm: Fine-grained, laminated, silicified tuffaceous shale (Text-fig. 4h)}

Lamination is formed by glass shards, mostly 100-150 $\mu \mathrm{m}$ in size, with a variable degree of alteration. The matrix is very fine-grained, homogenous and silicified. A preliminary $\mathrm{X}$-ray analysis indicates the presence of quartz as a main component, followed by goethite and orthoclase. Mica minerals, probably muscovite and paragonite as well as mixed-layered clay minerals (illite/smectite) occur as a minor phase. Interpretation of barren, fine-grained, tuffaceous shale associated with fossiliferous shallow-water volcanocarbonate succession is difficult due to limited exposure and the fact that only a single thin section was studied from this level. The close association of proximal and distal deposits could be explained by syndepositional faulting (Kř́̌ž 1991) but due to the strong tectonization, a possibility that the tuffaceous rock is not in its original position, should be also taken into consideration.

\section{Interval 340-350 cm: Crinoidal grainstone (Text-fig. 5a)}

Densely packed, moderately well-sorted crinoidal grainstone with fragmentary preserved brachiopods, ostracods, trilobites, and bryozoans. The sizes of the bioclasts range up to $2 \mathrm{~cm}$, but most commonly are between 1-2 mm. Volcanic products are present, but not as massively as in the underlying beds. Sponge spicules, which were among the most abundant allochems in the underlying beds, are missing here. Silicification of the bioclasts are observed to the same extent as in the underlying beds.

\section{Hýskov 2016-C - pilot sample (Text-fig. 5b, c)}

Laminated, fine-grained, moderately well sorted skeletal grainstone with peloids and fragmentary preserved bioclasts, with an average size of 150-250 $\mu \mathrm{m}$. Crinoid ossicles and ostracods are very abundant, followed by thin-walled brachiopods and trilobites. Rare occurrences of fragments of bryozoans, rugose corals, and an abraded "Girvanella" cluster were recorded. Bioclasts are silicified. Common syntaxial calcite overgrowth of silicified echinoderm remains are present. Several stages of allochem micritization were observed (from micritic envelopes to peloids). Volcanic products are common, although not as abundant as in the studied section. The facies is interpreted as gravity flow deposits from a shallow water environment situated in the photic zone as inferred by the presence of micritized grains, peloids, and calcimicrobes. 

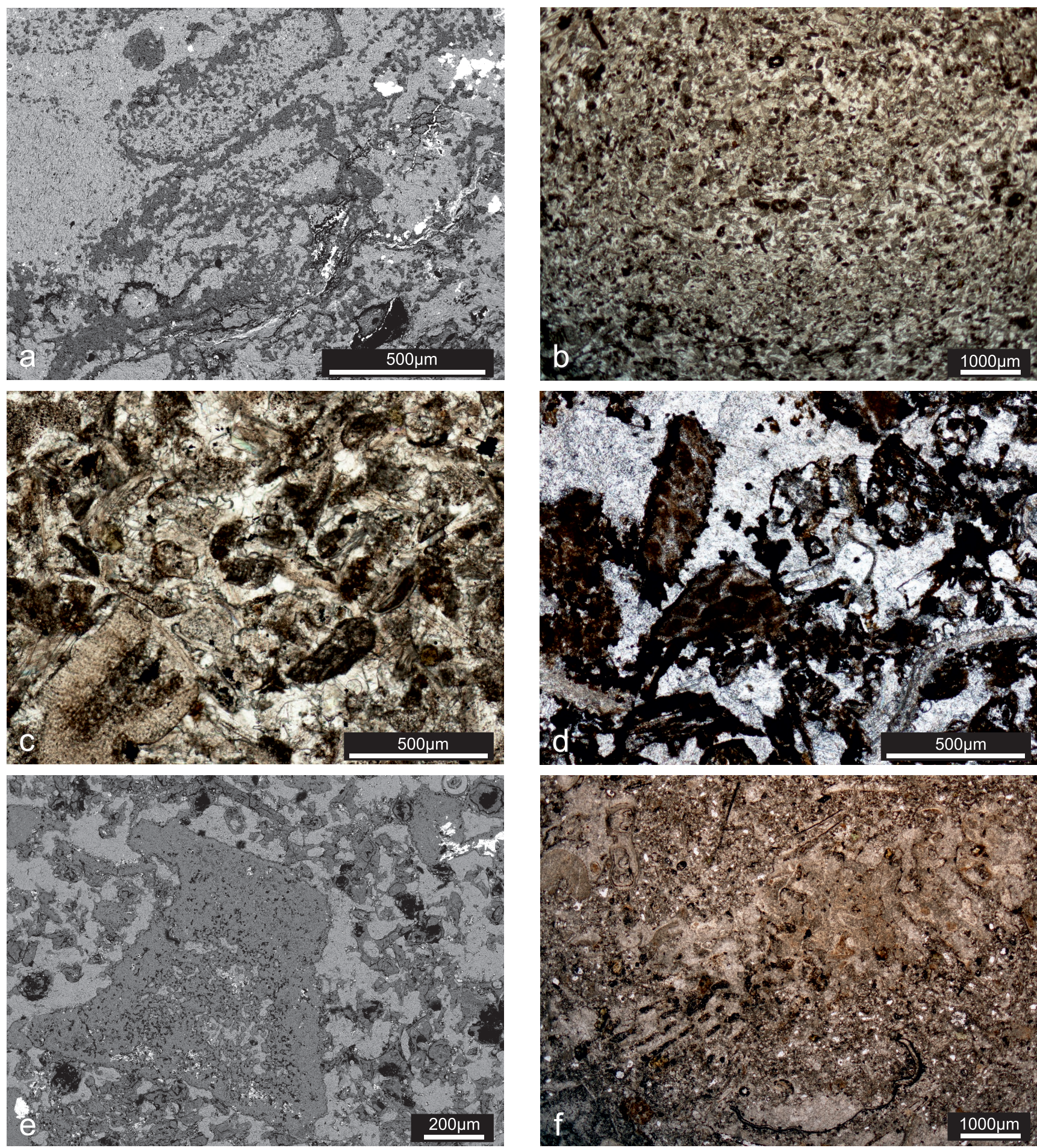

Text-fig. 5. (a) Examples of non-pervasive silicification of echinoderm remains. Interval $340-350 \mathrm{~cm}$ above the base of the section. (b) Moderately well-sorted peloidal grainstone with crinoid ossicles. Loose pilot sample Hýskov 2016-C. (c) Micritized grains in peloidal grainstone, note cluster of Girvanella in the center. Loose pilot sample Hýskov 2016-C. (d) Abraded clasts derived from calcareous green algae. Interval 40-50 cm above the base of the section. (e) Examples of non-pervasive silicification of echinoderm remains. $130 \mathrm{~cm}$ above the base of the section. (f) Articulated sponge skeleton. $130 \mathrm{~cm}$ above base of the section.

\section{Summary and facies interpretation}

Except for the lowermost part, the section is formed by poorly sorted to moderately well sorted, well-washed grainstones/rudstones/floatstones with fragmentary preserved bioclasts. The interlayering of a moderately well sorted grainstone matrix, mainly formed by volcanic glass shards and unidentified skeletal debris, with poorly sorted, fragmentary preserved bioclasts, points to a variable current intensity and episodic deposition. Laminae formed by skeletal accumulations, when not obscured by bioturbation, are ca. 5-15 mm thick. Echinoderm fragments are dominant; sponge spicules and ostracods are abundant, followed by brachiopods, trilobites, bryozoans, gastropods, and both rugose as well as tabulate corals. Bioclasts are fragmentarily preserved, brachiopod shells are mostly disarticulated, except in sample $240-255 \mathrm{~cm}$. 
The energy-related depositional setting can be interpreted as a succession of lower energy (skeletal accumulations in argillaceous matrix) and higher energy settings with skeletal grainstones, rudstones and floatstones, with a moderately well sorted matrix and poorly sorted, sharp skeletal accumulations. Although only a limited exposure was available for the study (ca. $4 \mathrm{~m}$ ), an alternation of different and probably depth controlled energy regimes was apparent. However, the differences were not significant as the energy levels were (except for the base of the section) still high enough to prevent deposition of lime mud (both inter and intra-particle micrite is missing). Therefore, a deposition in agitated, turbulent waters above the storm wave base is suggested herein. Rapid sedimentation and burial is assumed, supported by the lack of bioerosion and micritization, the rare find of an articulated sponge skeleton in the $130 \mathrm{~cm}$ sample (Text-fig. 5f), preservation mode of the larger brachiopod shells (not crushed, articulated), and common occurrence of umbrellasheltering zones filled with sparite.

The composition of bioclasts points to transport from the open marine, normal salinity, and oxygenated environment (crinoids, ostracods, brachiopods, gastropods, trilobites). Bioherm associated elements (rugose and tabulate corals, bryozoans and calcareous green algae) are present although not abundant. The occurrence of hexactinellid sponge spicules in such an environment is rather surprising, as more quiet-water facies are thought to be the typical environment for sponges. In general, the record of Early Palaeozoic sponges is very sparse (Muir et al. 2013), and only a handful of studies report their occurrence in a shallow, agitated environment (Botting 2005, Beresi et al. 2006, Rhebergen and Botting 2014). Except for samples from the levels $0 \mathrm{~cm}, 260-280 \mathrm{~cm}$ (tuffaceous layer) and 340-350 cm, sponge spicules were among the most abundant components. Their occurrence was recorded even in poorly sorted skeletal rudstone (185 cm sample), which is interpreted as the most proximal facies, deposited in the most agitated environment. As mentioned above, micritized grains and peloids were not observed within the studied section (only in the loose Hýskov 2016-C sample). Thus the only direct proof for the photic zone as a source area of the allochems is provided by the presence of abraded calcareous green algae.

Silicification observed within the entire studied interval tends to be non-pervasive, leaving certain inner parts of shells calcitic, especially in thicker brachiopods, trilobite exoskeletons, rugose coral walls, and echinoderm remains (Text-fig. 5a, e). Silicification is restricted only to bioclasts and not to carbonate cement, suggesting early silification, which is further supported by the common syntaxial calcite overgrowth of silicified echinoderm remains. Silicification affects all bioclasts, and no selective silicification was observed. Although hexactinellid spicules are abundant in the studied beds, active volcanism most likely provided the main source of silica.

\section{Microfossils}

\section{Scolecodonts (polychaete jaws)}

Llandovery scolecodonts have been less well studied than the younger Silurian material worldwide (summary in Eriksson et al. 2004). From the Prague Basin, there are only very few papers reporting scolecodonts from the entire Silurian (summary in Tonarová et al. 2012), and so far with no reports of scolecodonts from the Želkovice Formation. The main reason for this is probably that the prevailing black shale facies usually contains only badly preserved organicwalled microfossils. However, in the Hýskov section, nine samples proved productive for scolecodonts (Text-fig. 3), and at some levels they appear to be excellently preserved (Pl. 1; probably the best preservation so far recorded from the Prague Basin). The upper part of the newly opened pit was barren for scolecodonts, although these samples contained common gastropods, brachiopods, ostracods, conodonts, crinoids, trilobites, and rarely chitinozoans. The abundance of scolecodonts is relatively low in most samples, starting from 1 specimen per $\mathrm{kg}$, but reaching up to ca. 200 maxillae per $\mathrm{kg}$ of rock in sample Hýskov 2016-C, which is comparable to what has been recorded in Ordovician and Silurian strata elsewhere (e.g. Hints 2000, Eriksson et al. 2004), but also in the younger Silurian strata of the Prague Basin (Tonarová et al. 2012). The entire Hýskov scolecodont collection contains approximately 300 posterior maxillae. The number of species per sample ranges from 1 to 12 , and altogether at least 16 genera and at minimum 20 species are present. Selected taxa are illustrated in Plate 1.

The jawed polychaete fauna of the Hýskov section contains the same (or very similar) taxa as in the better known assemblages from Baltica (see Eriksson et al. 2004, Hints et al. 2006, Tonarová et al. 2014). Scolecodonts are the most abundant (11 species, 114 specimens per $\mathrm{kg}$ of rock), diverse, and best preserved in the lowermost part of the section, sample $0 \mathrm{~cm}$, which is represented by tuffaceous mudstone-wackestone with skeletal packstone laminae. In the overlying beds scolecodonts occur in lower numbers (3 to $30 / \mathrm{kg}$ ), and often are fragmentarily preserved. The last occurrence of scolecodonts was recorded in the $170-180 \mathrm{~cm}$ sample. The abundance of scolecodonts in mud-supported facies, and their absence in the coarser-grained grainstones and rudstones deposited in an agitated environment, is in agreement with the findings of Eriksson et al. (2004), who suggested that the poor record of scolecodonts in wellwashed grainstones and reef flank sediments could be due to taphonomy rather than a result of non-colonization by polychaetes. The best preserved scolecodonts and the greatest abundance and diversity (200/kg, 12 species) was recorded from the pilot sample Hýskov 2016-C, represented by moderately well-sorted crinoidal grainstones with micritized grains and peloids. This facies is interpreted herein as a gravity flow deposit, with the source area being located in the photic zone as inferred from the occurrence of micritized grains, peloids, and rare fragments of calcimicrobe Girvanella NichOLSON et Etheridge, 1878. Bearing in mind the high abundance and diversity of scolecodonts in this sample, the photic zone with microbial mats seems to represent an ideal environment for polychaetes. This is also supported by the recorded occurrence of representatives of the genera Symmetroprion KIELAN-JAWOROWSKA, 1966, which according to Bergman (1995) preferred lagoonal and reefal environments, and Dubichaetaspis ERIKSSON, 1998, which according to Eriksson (1998) preferred similarly shallow warm waters, in close proximity to reefs. 
The most abundant taxonomic group represented in the Hýskov polychaete fauna are the polychaetaspids, followed by xanioprionids. All of the other identified families (mochtyellids, paulinitids, ramphoprionids, atraktoprionids, tetraprionids, skalenoprionids, kalloprionids, and symmetroprionids) are far less common.

Polychaetaspids are represented by at least four species of the genus Oenonites Hinde, 1879, with the most distinct one being O. jennyensis ERIKSSON, 1997 (Pl. 1, Figs 1-5); the other species are indicated as Oenonites spp. on the range chart (Text-fig. 3) due to difficulties in reconstructing the jaw apparatus based on relatively limited material. $O$. jennyensis is a common species in the Llandovery and Wenlock of Sweden and Estonia (Eriksson 1997, Hints et al. 2006). In addition, Dubichaetaspis bergmani ERIKSSON, 1998 (Pl. 1, Fig. 6) and Incisiprion? sp. (Pl. 1, Fig. 8) have been identified in a few samples; both forms also being known from the Baltic region.

The second most common family, the Xanioprionidae, is represented by Xanioprion cf. borealis KIELAN-JAWOROWSKA, 1962 (Pl. 1, Figs 30, 31, 33-35, 37) and possibly another species. It is noteworthy that Eriksson (2006) and Tonarová et al. (2014) observed a high relative abundance of xanioprionids soon after the main extinction phase of the Ireviken Event.

Paulinitids are far less common in the Hýskov section than in other Silurian samples studied from the Prague Basin (Tonarová 2008, Tonarová et al. 2012), and are usually only preserved as fragments; therefore, specieslevel identification is not possible, and all paulinitid jaws are treated here as Kettnerites sp. (P1. 1, Figs 20, 21).

Among ramphoprionids only the genus Protarabellites STAUFFER, 1933 is present in the Hýskov fauna (however, the genus Ramphoprion KiELAN-JaWOROWSKA, 1962 is known from the Late Ordovician strata of the Prague Basin; PT, unpubl. data). Two species of Protarabellites were recovered, both well-known in Baltoscandia - Protarabellites staufferi? ERIKSSON, 2001 (Pl. 1, Figs 10, 11, 13) and P. triangularis ERIKSSON, 2001 (Pl. 1, Fig. 12); the latter only having been found in one sample, Hýskov 75-80 cm (Text-fig. 3).

Kalloprionids are represented by Kalloprion KIELANJAWOROWSKA, 1962 and Leptoprion KiELAN-JAWOROWSKA, 1966 (P1. 1, Figs 23, 24), but for both genera more precise identification is not possible at the present time.

Atraktoprionids, here treated as Atraktoprion sp., are rare, only occurring in samples Hýskov $0 \mathrm{~cm}$ and Hýskov 2016-A and 2016-C. However, at least two different species are present, one similar to $A$. cornutus KiElan-JAwOrowsKA, 1962 (Pl. 1, Figs 14-16), and the other one possessing a much larger hook and shorter shank (Pl. 1, Fig. 22). The former species (or a group of closely related species) has previously been recorded from both the Ordovician and Silurian strata in different regions (e.g. Kielan-Jaworowska 1966, Hints 1998, Hints et al. 2015, 2016).

The single symmetroprionid species Symmetroprion spatiosus (Hinde, 1882) (Text-fig. 3, Pl. 1, Fig. 19) is very rare, occurring only in Hýskov-2016 samples. Morphologically it is indistinguishable from the Baltic material reported by Bergman (1995) and from the author's unpublished collections.

Mochtyellids are represented by the genera Pistoprion KiElAN-JAWOROWSKA, 1966, Vistulella KiELAN-JAWOROWSKA,
1961, and Mochtyella KIELAN-JAWOROWSKA, 1961, which often predominate Late Ordovician and early Silurian polychaete assemblages in Baltica (Hints et al. 2006, Tonarová et al. 2014). In the Hýskov section they are less abundant, but taxonomically very similar to the Baltic fauna. For example, Pistoprion transitans KiElan-JaWOrOWSKA, 1966 (Pl. 1, Fig. 26) is a long-ranging species, very common in the Hirnantian as well as in the basal Rhuddanian strata (Hints et al. 2010, 2016), with the youngest specimens recovered from the early Wenlock (Hints et al. 2006). The genus Pistoprion is considered as an environmentally sensitive taxon, showing preferences for shallow-water settings (Hints 2000). The genus Mochtyella is represented by several species, including $M$. aff. trapezoidea KIELANJAWOROWSKA, 1966 (Pl. 1, Fig. 28), which is yet another geographically and stratigraphically widespread taxon.

Tetraprionids are identified from the lowermost samples as Tetraprion sp. (P1. 1, Fig. 36), which is probably closely related to, if not conspecific with, a taxon first described by Szaniawski (1970) as ?Tetraprion sp. Similar forms are known from the Ordovician and Silurian of different regions. Additionally, a single specimen of an enigmatic placognath jaw tentatively assigned to the genus Lunoprionella EISENACK, 1975 was found (Pl. 1, Fig. 9) from sample Hýskov 2016-A. A very similar species is known from the Late Ordovician of Baltica as "Lunoprionella" sp. A by Hints (1998), as well as from the Ordovician-Silurian boundary beds (OH and PT, unpublished data).

Overall, the polychaete fauna recovered from the Hýskov section includes the best preserved scolecodonts from the Prague Basin so far. The assemblage is moderately diverse and taxonomically extremely similar to roughly contemporaneous faunas previously reported from Baltoscandia, but also from other regions. The same conclusion on the biogeographic pattern were made by both Tonarová et al. (2012) and Eriksson et al. (2013). Several facies-controlled polychaete species allow for further constraining the palaeoenvironmental setting of the section. However, in terms of biostratigraphy, the recovered scolecodonts are less useful, as most of the species range through the Llandovery and Wenlock, and some originate from the Ordovician.

\section{Conodonts}

Conodonts from the Hýskov locality have not been described in any detail in previous studies. Havlíček and Kříž (1973) only mentioned the results of preliminary determination by Schönlaub, who recognized the assemblage of middle to upper Llandovery age. During our study, 236 identifiable conodonts were recovered in six samples from the measured section and in three samples taken from the loose material. Surprisingly, the preservation of specimens in these two sets of samples is rather different: those from the measured section are in most cases poorly preserved (broken, surfaces recrystallized, some mineral particles attached to the surface of an element - Pl. 2, Figs 1-6, 8, 9, 11); whereas specimens from the loose blocks are much better preserved (Pl. 2, Figs 7, 10, 12-19). Also, the general composition of the conodont assemblages in these two sets of samples is different. The limited number of specimens, their general poor state of preservation, but also the lack 
of any possibility to study the specimens directly by PM (identifications in this paper are only based on photos) complicated their identification.

The most common taxa in the measured section are Walliserodus sp. and Oulodus? sp. (Text-fig. 3, Pl. 2, Figs $3,5,8,9$ and 2, 11 respectively). Elements of both taxa are too poorly preserved to allow species-level identification. In general, the illustrated specimens of Walliserodus sp., particularly the deboltiform element (Pl. 2, Fig. 3), look similar to the elements of Walliserodus sp. n. C of Männik (2008: fig. 10: O, T, U), which in the Baltic region appears in the lowermost Wenlock (Loydell et al. 2010, Männik and Nestor 2014), and is characteristic of the Sheinwoodian. However, the illustrated specimens also display some similarities to Acodus unicostatus s.f., Paltodus debolti s.f. and Paltodus dyscritus s.f. described by Rexroad (1967: pl. 4, figs 13-16, 22-25 and 30-34, respectively); later recognized as elements of W. curvatus (BRANSON et BRANSON, 1947) occurring in the Rhuddanian and Aeronian (e.g. Zhang and Barnes 2002 and references therein). Unfortunately, as the species-diagnostic migratiform element of Walliserodus SERPAngli, 1968 is missing in the Hýskov collection, it is not possible to ascertain to which species our elements might belong (for details see Rexroad 1967: pl. 4, figs 1-21 for $W$. curvatus; and Loydell et al. 2010: fig. 9: ii, indicated as a multicostatiform element, for Walliserodus sp. n. C).

From the lowermost sample in the measured section a specimen of Pseudooneotodus Drygant, 1974, very similar to Ps. linguicornis Jeppsson, 2003 (identified here as Ps. aff. linguicornis, Text-fig. 3, Pl. 2, Fig. 4) has been illustrated. Ps. linguicornis occurs in the uppermost Sheinwoodian lower Homerian strata corresponding to the Ozarkodina sagitta Conodont Zone as well as in the strata just below it (Calner and Jeppsson 2003). However, our specimen differs from the typical Ps. linguicornis: instead of a distinct short ridge-like tip characteristic of Ps. linguicornis (Calner and Jeppsson 2003: fig. 15a-1), the Hýskov specimen seems to have a pointed top (P1. 2, Fig. 4).

A single element of Distomodus sp. was recovered from the 40-50 cm sample (Text-fig. 3, Pl. 2, Fig. 6), and a probable element of Ozarkodina ex gr. oldhamensis (REXroAd, 1967) from the $190 \mathrm{~cm}$ sample (Text-fig. 3, P1. 2, Fig. 1). However, the general configuration of the latter specimen is somewhat unusual, and not particularly characteristic of the elements of the Oz. oldhamensis group. The Pa elements of $\mathrm{Oz}$. oldhamensis are almost straight in lateral view (e.g. Rexroad 1967: pl. 3, fig. 3), whereas both processes of our specimen seem to be distinctly turned upwards making it somewhat similar to the Pa elements of Zieglerodina Murphy, Valenzuela-Rios et CARls, 2004 (e.g. Murphy et al. 2004: fig. 3: 3). However, it cannot be excluded that the morphology of our specimen results from deformation or an unfavorable imaging angle.

The most common taxon in the samples from loose material is Dapsilodus sp. (Text-fig. 3, Pl. 2, Figs 16, 19), the specimens of which in general configuration are quite similar to those of Dapsilodus sp. n. R, occurring in the Baltic region in the Rhuddanian and Aeronian (Loydell et al. 2010, Männik et al. 2015). The late Rhuddanian - Aeronian age of samples Hýskov 2016-C and 2017-D is inferred from a single specimen of Wurmiella cf. puskuensis (MÄNNIK,
1994) (Text-fig. 3, Pl. 2, Fig. 14). W. puskuensis is known from the upper Rhuddanian and Aeronian strata in the Baltic region (Nestor et al. 2003; identified as Oz. excavate puskuensis), but has also been reported from South China (Wang and Aldridge 2010).

The single specimen of $\mathrm{Oz}$. aff. aldridgei UYENO et BARNES, 1983 in our collection comes from sample Hýskov 2017-D (Text-fig. 3; P1. 2, Fig. 17) and is generally similar to Oz. aldridgei (Uyeno and Barnes 1983: pl. 3, figs 16, 17); however, in our element the interval of completely fused denticles above the basal cavity is considerably longer. In that sense, our specimen is also similar to Oz. oldhamensis as illustrated in Zhang and Barnes (2002: fig. 13: 38, 39). Oz. aldridgei is described from the upper Aeronian, but Oz. oldhamensis sensu Zhang and Barnes (2002) occurs in the Rhuddanian - lower Aeronian. Conodonts identical to Pseudooneotodus aff. beckmanni (Bischoff et SANnEMAnN, 1958) (Text-fig. 3, Pl. 2, Fig. 18) occur in the Baltic sections and also in the Rhuddanian and Aeronian interval, but already appear in the Upper Ordovician (e.g. Männik 2003; identified as Ps. ex gr. beckmanni). Panderodus equicostatus (RHodes, 1953) found in the samples Hýskov 2016-B and 2016-C (Text-fig. 3; P1. 2, Figs 7, 13) is common in several intervals in the Silurian, also including the Rhuddanian and Aeronian, but is for the most part missing (rare specimens only found in a few short intervals) in the Telychian (Männik 2003). This taxon in also known from the Upper Ordovician.

The age of the three samples from the loose material could be unambiguously dated as Rhuddanian - Aeronian (sample Hýskov 2017-D might be of late Aeronian, above), but the precise age of the measured section based on conodonts (i.e. based on available images) remains problematic. The available data allow controversial conclusions to be drawn: Ps. aff. linguicornis suggests a middle Wenlock age, but might also indicate that the Ps. linguicornis lineage appeared earlier than previously known; Distomodus sp. indicates that the sample from $40-50 \mathrm{~cm}$ cannot be younger than the early Sheinwoodian (but might come from any level within the Llandovery); the illustrated elements of Walliserodus sp. might belong either to W. curvatus or Walliserodus sp. n. C, suggesting a Rhuddanian - Aeronian or Sheinwoodian age, respectively; the single specimen of Ozarkodina ex gr. oldhamensis probably dates the sample as Rhuddanian - Aeronian. For more reliable identifications and biostratigraphic dating additional material and firsthand study of the collection are needed.

\section{Chitinozoans}

Hýskov chitinozoans were first reported by Dufka (1992), who identified two genera and four species from the section: Cyathochitina caputoi DA CosTA, 1970, Conochitina cf. edjelensis TAugourdeau, 1963, Conochitina iklaensis Nestor, 1980, and Conochitina emmastensis Nestor, 1982. Chitinozoan fauna from the current sampling campaign is more diverse, with at least four genera and possibly eight species present (Pl. 3). In total ca. 460 identifiable specimens were found. The abundance varies from 1 to almost 200 (in the most productive Hýskov $0 \mathrm{~cm}$ sample) chitinozoans per $\mathrm{kg}$ of rock. Preservation of the material is variable, ranging from flattened specimens (Pl. 3, Figs 12, 21) and pyritic casts 
without any organic-walled material left (Pl. 3, Figs 14, 15) to three-dimensionally preserved vesicles (Pl. 3, Figs 17, 18). The best preserved assemblage comes from the loose material. In many cases, the state of preservation and the relatively small number of specimens limits species-level identification. For instance, if the diagnostic processes of Ancyrochitina spp. cannot be studied, species determination becomes complicated or impossible. For this reason, the chitinozoan fauna is characterized using open nomenclature and comparisons with previous studies rather than with firmly identified species. The chitinozoan assemblage is dominated by Conochitina EISENACK, 1931, followed by Cyathochitina EISENACK, 1955, Ancyrochitina EISENACK, 1955, and Bursachitina TAugourdeAu, 1966 (Text-fig. 3).

Cyathochitina is especially common in the loose samples and also in the basal part of the measured section. Some specimens of recovered Cyathochitina are very similar to the material illustrated by Dufka (1992), and identified as C. cf. campanulaeformis (EISENACK, 1931) and C. caputoi DA CosTA, 1970. Additionally, typical forms of $C$. campanulaeformis were recovered, indistinguishable from those reported from the Upper Ordovician to Rhuddanian strata of Baltoscandia (e.g. Nestor 1994). Based on the limited material available, it is not entirely clear if the South American C. caputoi truly occurs in the studied samples, but some specimens are indeed very similar in size and shape to the holotype of C. caputoi (da Costa 1971: pl. 15, fig. 7). However, studies from the Baltic region have revealed high variability in the $C$. campanulaeformis group, including the co-occurrence of both long and short-necked specimens with intermediate forms in the same samples. Thus, we tentatively assign most of the Hýskov Cyathochitina specimens to C. cf. campanulaeformis, leaving the question if one or more species are present in the collection an open one for the time being.

Ancyrochitina spp. (Pl. 3, Figs 3-6) was so far only recovered from the loose samples. Due to incomplete preservation, the material cannot be fully identified (as was the case with Dufka's collection), but probably two different species are present in the samples studied (cf. Pl. 3, Figs 4, 6).

Bursachitina sp. is identified by a few specimens only occurring in the lowermost sample measured. By vesicle size and shape, they are very similar to some forms of Eisenackitina JANSONIUS, 1964; however, with glabrous rather than spiny or granular ornamentation (Pl. 3, Figs 1, 2).

Conochitina occurs in all productive samples, but distinguishing different species is problematic due to the poor preservation and the wide range of variability. For that reason, many individual specimens have been assigned to Conochitina spp. on the range chart (Text-fig. 3). Conochitina cf. iklaensis, mentioned from the section by Dufka (1992: pl. 2 , figs 16,17$)$, is only identified from the $240 \mathrm{~cm}$ sample (Pl. 3, Fig. 13), although some broken specimens from other samples may belong to the same species. In several samples C. cf. edjelensis elongata sensu Dufka 1992 (Pl. 3, Figs 21-23) and C. cf. edjelensis sensu Dufka 1992 (Pl. 3 , Figs 24-27) are common. The former is considered as a separate species, C. elongata TAUGOURDEAU, 1963, rather than a subspecies well known from the upper Aeronian of the Baltic region (e.g. Nestor 2012 and references therein). However, the latter form has been assigned to different taxa in previous work; for instance, Hints et al. (2006: pl. 1, fig. 11) illustrated a very similar and probably conspecific form as Conochitina malleus (VAN GRoOTEL, 1990) from Estonia, whereas Männik et al. (2015: fig. 6z) used the name Bursachitina conica (TAUGOURDEAU et DE JEKHOWSKY, 1964) for nearly identical specimens from the Grötlingbo borehole, Gotland. In this report we use the name $C$. cf. edjelensis sensu Dufka 1992, as our specimens match those therein most closely.

Only a few specimens from the present collection can be assigned to Conochitina cf. emmastensis (Pl. 3, Figs 19, 20), which differ from the typical Baltic specimens in having a less conspicuous mucron. Additionally, some specimens resemble Conochitina malleus (Pl. 3, Fig. 18), previously recorded from the slightly older strata in the Prague Basin (Dufka 1992), and Conochitina alargada CRAMER, 1967 (Pl. 3 , Fig. 14), not mentioned earlier from the region. The latter species was originally also described as a subspecies of $C$. edjelensis, and is currently used as a late Aeronian zonal index in the Baltic region as well as globally (Verniers et al. 1995, Nestor 2012). However, its distinguishing is difficult due to the co-occurrence of very similar and morphologically variable taxa in the same stratigraphic interval (Nestor 1994).

Overall, regardless of the taxonomic uncertainties, the chitinozoan fauna recovered from the Hýskov section fits well with the previous data from the Prague region and Baltoscandia. The diversity of the chitinozoan assemblage appears to be higher than previously reported by Dufka (1992), containing no less than eight different species. This interval represents the start of the rapid diversification of chitinozoans following the end-Ordovician extinction, and then by a slow recovery period (Paluveer et al. 2014, Hints et al. 2018). Biostratigraphically, the assemblage corresponds best to the $C$. alargada Biozone, lacking elements from the under- and overlying zones, and providing additional biostratigraphic constraint for the section. Also, based on the chitinozoan assemblage, the loose samples stratigraphically best fit to the lower part of the measured section, or below from the lowermost measured sample.

\section{Discussion}

When taking facies development into account, it is obvious that the facies encountered within this study differ from the facies recorded by previous authors. For instance, Kříž (1991: 184) described the sequence as tuffaceous and calcareous shales with tuffaceous laminated limestones. Štorch (2001) recorded tuffaceous, calcareous shale muddy limestones and micritic limestones with fragmentary preserved bioclasts concentrated in distinct laminae (test pit 226), poorly sorted, coarse trilobite-brachiopod-crinoidal grainstones (test pit DB 223) and lime mudstones, with brachiopods and common dendroids as well as planktic graptoloids, representing the uppermost part of the sequence (test pit DB 222). The studied sequence herein starts with tuffaceous mudstones and wackestones with skeletal concentrations forming layers a few millimeter-thick in a laminated tuffaceous, argillaceous matrix. Above this, only well-washed skeletal grainstones, rudstones and floatstones were recorded. Based on published lithological descriptions 
it therefore seems that the sequence encountered within this study could possibly correspond to the middle part of the sequence published by Štorch (2001: fig. 2, test pit 223), composed of packstones and coarse crinoidal grainstones, which according to the above mentioned author, represent a considerable shallowing. However, Štorch (2001: 58) described allochems with micritized rims and, as mentioned above, no micritization was observed within the measured section. Micritization and peloids were only observed in the Hýskov 2016-C sample, representing a loose pilot sample. Based on facies development, it therefore appears that the measured section represents a different stratigraphic level than the sections studied by previous authors.

No graptolites were found from the measured section, but conodonts and chitinozoans provide some age constraints. The assessment of conodont faunas was hampered by their generally bad preservation and the fact that upper Aeronian conodonts are poorly known in most regions due to the sea level fall (Loydell 1998) and a break in sedimentation known as the Panuara Hiatus (Jell and Talent 1989). However, the single find of Ozarkodina ex gr. oldhamensis indicates a Rhuddanian - Aeronian age. Secondly, the specimens of Walliserodus sp., showing similarities with $W$. curvatus, also support a Rhuddanian - Aeronian assignment. The chitinozoan assemblage recovered from the measured section corresponds most closely to the Conochitina alargada Biozone. Notably, the assemblage is lacking the characteristic elements from the Rhuddanian and Telychian faunas.

Chitinozoan and scolecodont assemblages from the basal part of the measured section, represented by tuffaceous skeletal wackestones and tuffaceous mudstones, clearly correlate with the loose pilot samples (Hýskov 2016-C and Hýskov 2016-B). The pilot samples are represented by crinoidal grainstone with peloids, such as were described by Štorch in the test pit DB 223 (Štorch 1986: 89). In addition, graptolites of the sedgwickii Zone were recorded in the pilot samples (Štorch, pers. comm. 2018) and can therefore be correlated with the sections described by previous authors. Consequently, it seems most probable that the measured section stratigraphically represents a younger succession, and only its lowermost part could be correlated with the previously described sections. It follows that the age of the measured section most likely corresponds also to the late Aeronian.

As mentioned above, according to Storch (2001), the globally recognized sea-level fall in the lower sedgwickii Zone could account for the immigration of taxa with an affinity to British-Scandinavian and Baltic regions. Such new faunal elements were recognized among trilobite, dendroid, brachiopod, acritarch and chitinozoan communities in the Hýskov succession (Šnajdr 1978, Kraft 1982, Havlíček and Štorch 1990, Dufka 1990, 1992). Our new data on microfossils corroborate this pattern and show that all three different groups had close biogeographic links with other regions, notably Baltica.

Ordovician - Silurian jawed polychaete biogeography has been discussed thoroughly by Eriksson et al. (2013). These authors provided several examples of intercontinental distribution of Silurian polychaete species and the present report further extends this list by e.g. Symmetroprion spatiosus, Dubichaetaspis bergmani and Oenonites jennyensis. It is known that the Ordovician jawed polychaete faunas had significantly less cosmopolitan taxa in general than the Silurian ones (Hints and Eriksson 2007, Eriksson et al. 2013). What remains to be studied, however, is when and how the Silurian-type biogeographic patterns emerged. For instance, we still have limited understanding which regions were the main diversification centres and where were the main migration routes. For this, additional material from the Late Ordovician and early Silurian is needed, along with better geographic coverage.

\section{Conclusions}

The main results of our study based on new material from the Hýskov section can be summarized as follows:

(1) The microfacies analysis indicates deposition in lower energy settings (tuffaceous mudstone-wackestone with skeletal accumulations) and agitated, storm-influenced settings (well-washed, skeletal grainstones, rudstones and floatstones). The allochem assemblage recorded is suggestive of transport from the open marine, normal salinity and oxygenated environment (crinoids, ostracods, brachiopods, gastropods, trilobites) with locally common occurrences of bioherm associated elements (rugose and tabulate corals, bryozoans and calcareous green algae). Hexactinellid sponge spicules are among the most common components, making the Hýskov section a unique example of a shallow-water, agitated environment inhabited by hexactinellid sponges, only a handful of which have so far been recorded in the Lower Palaeozoic.

(2) Preservation of microfossils turned variable, reaching excellent in some samples. For scolecodonts, this includes the best preserved Silurian material from the region so far documented.

(3) Conodont and chitinozoan biostratigraphy allows dating the studied Hýskov section as late Aeronian, with only the basal part of the measured section corresponding to the stratigraphic level of previous studies of the locality.

(4) For the first time, the taxonomic composition and diversity of Llandovery jawed polychaete fauna was reported from the Prague Basin, complemented by the data on conodonts and chitinozoans. The reported microfossil assemblages represent the time interval from which little data worldwide are available due to sea level lowstand and hiatus.

(5) The greatest abundance and diversity of scolecodonts was recorded in peloidal grainstones, the source of which are interpreted as a shallow-water, photic zone environment with microbial communities. This represented an ideal habitat for polychaetes, as is further supported by the occurrences of the shallow-water taxa Symmetroprion and Dubichaetaspis.

(6) Biogeographically, the assemblages of both benthic polychaetes as well as planktonic chitinozoans and nectonic conodont animals show a great similarity to contemporaneous faunas of the Baltic region and elsewhere. For instance, among the polychaete taxa, all genera and species are in common with the better known faunas of Baltoscandia.

(7) Finally, the high diversity and relatively good preservation of microfossils in the Hýskov section points 
to the potential for obtaining additional material to further constrain the stratigraphic position and biofacies, and for a more comprehensive taxonomic study of all three groups.

\section{Acknowledgements}

We wish to thank Mr. Sevald for permission to work on his land. The study was supported by projects GJ15-13525Y and GA17-10233S from the Czech Science Foundation, 339900 and 331000 from the Czech Geological Survey, as well as PUT611 from the Estonian Research Council. This paper is a contribution to IGCP 653. We thank Petr Štorch (Institute of Geology of the Czech Academy of Sciences, Prague, Czech Republic) for graptolite identifications. We thank reviewers Anthony Butcher (University of Portsmouth, United Kingdom) and Mark Kleffner (The Ohio State University, Columbus, United States) for their comments that enhanced the quality of the manuscript.

\section{References}

Beresi, M. S., Aceñolaza, G., Nieva, S. (2006): Cambro-Ordovician sponges and spicule assemblages from Northwest Argentina: new data from the siliciclastic platforms of western Gondwana. - Neues Jahrbuch für Geologie und Paläontologie, Monatshefte, 2006(7): 403-420.

Bergman, C. F. (1995): Symmetroprion spatiosus (Hinde), a jawed polychaete showing preference for reef environments in the Silurian of Gotland. - GFF, 117: 143-150. https://doi.org/10.1080/11035899509546210

Botting, J. P. (2005): Exceptionally-preserved Middle Ordovician sponges from the Llandegley Rocks Lagerstätte, central Wales. - Palaeontology, 48: 577-617. https://doi.org/10.1111/j.1475-4983.2005.00470.x

Bouček, B. (1957): The dendroid graptolites of the Silurian of Bohemia. - Rozpravy Ústředního ústavu geologického, 23: 1-239.

Calner, M., Jeppsson, L. (2003): Carbonate platform evolution and conodont stratigraphy during the middle Silurian Mulde Event, Gotland, Sweden. - Geological Magazine, 140: 173-203. https://doi.org/10.1017/S0016756802007070

Chlupáč, I., Havlíček, V., Kř́iž, J., Kukal, Z., Štorch, P. (1998): Palaeozoic of the Barrandian (Cambrian to Devonian). - Czech Geological Survey, Prague, 183 pp.

da Costa, N. M. M. (1971): Quitinozoários Silurianos do Igarapé da Rainha, Estado do Pará [Silurian chitinozoans of Igarapé da Rainha, Pará State, Brasil]. - Ministério das Minas e Energia, Divisão de Geologia e Mineralogia Boletin, 255: 9-97. (in Portugese)

Dufka, P. (1990): Acritarchs of the Monograptus sedgwickii Zone (Želkovice Formation, Llandovery) from Hýskov, Barrandian, Bohemian Massif. - Acta Universitatis Carolinae, Geologica, 1990(1): 75-104.

Dufka, P. (1992): Lower Silurian Chitinozoans of the Prague Basin (Barrandian, Czechoslovakia) - preliminary results. - Revue de Micropaléontologie, 35(2): 117-126.

Eriksson, M. (1997): Lower Silurian polychaetaspid polychaetes from Gotland, Sweden. - GFF, 119(3): 213-230. https://doi.org/10.1080/11035899709546480
Eriksson, M. (1998): Dubichaetaspis bergmani gen. et sp. n., a facies controlled polychaete from the Silurian of Gotland, Sweden. - GFF, 120: 21-25. https://doi.org/10.1080/11035899801201021

Eriksson, M. E. (2006): The Silurian Ireviken Event and vagile benthic faunal turnovers (Polychaeta; Eunicida) on Gotland, Sweden. - GFF, 128: 91-95. https://doi.org/10.1080/11035890601282091

Eriksson, M. E., Bergman, C. F., Jeppsson, L. (2004): Silurian scolecodonts. - Review of Palaeobotany and Palynology, 131: 269-300. https://doi.org/10.1016/j.revpalbo.2004.04.001

Eriksson, M. E., Hints, O., Paxton, H., Tonarová, P. (2013): Ordovician and Silurian polychaete diversity and biogeography. - In: Harper, D. A. T., Servais, T. (eds), Early Palaeozoic Biogeography and Palaeogeography. Memoirs, Geological Society, London, 38: 265-272. https://doi.org/10.1144/M38.18

Frýda, J., Štorch, P. (2014): Carbon isotope chemostratigraphy of the Llandovery in northern peri-Gondwana: new data from the Barrandian area, Czech Republic. - Estonian Journal of Earth Sciences, 63(4): 220-226. https://doi.org/10.3176/earth.2014.22

Havlíček, V. (1977): Brachiopods of the Order Orthida in Czechoslovakia. - Rozpravy Ústředního ústavu geologického, 44: 1-327.

Havlíček, V., Kříž, J. (1973): Svrchní llandover a spodní devon u Hýskova (Barrandien) [Upper Llandovery and Lower Devonian near Hýskov (Barrandien)]. - Věstník Ústředního ústavu geologického, 48: 103-107. (in Czech with English Abstract)

Havlíček, V., Štorch, P. (1990): Silurian brachiopods and benthic communities in the Prague Basin (Czechoslovakia). - Rozpravy Ústředního ústavu geologického, 48: 1-275.

Hints, L., Hints, O., Kaljo, D., Kiipli, T., Männik, P., Nõlvak, J., Pärnaste, H. (2010): Hirnantian (latest Ordovician) bio- and chemostratigraphy of the Stirnas-18 core, western Latvia. - Estonian Journal of Earth Sciences, 59(1): 1-24. https://doi.org/10.3176/earth.2010.1.01

Hints, O. (1998): Late Viruan (Caradoc) polychaete jaws from North Estonia and the St. Petersburg region. - Acta Palaeontologica Polonica, 43: 471-516.

Hints, O. (2000): Ordovician eunicid polychaetes of Estonia and surrounding areas: review of their distribution and diversification. - Review of Palaeobotany and Palynology, 113: 41-55. https://doi.org/10.1016/S0034-6667(00)00051-8

Hints, O., Eriksson, M. E. (2007): Diversification and biogeography of scolecodont-bearing polychaetes in the Ordovician. - Palaeogeography, Palaeoclimatology, Palaeoecology, 254: 95-114. https://doi.org/10.1016/j.palaeo.2006.02.029

Hints, O., Antonovitš, L., Bauert, G., Nestor, V., Nõlvak, J., Tammekänd, M. (2018): CHITDB: a database for documenting and analysing diversification of OrdovicianSilurian chitinozoans in the Baltic region. - Lethaia, 51: 218-227. https://doi.org/10.1111/let.12249

Hints, O., Killing, M., Männik, P., Nestor, V. (2006): Frequency patterns of chitinozoans, scolecodonts, and cono- 
donts in the upper Llandovery and lower Wenlock of the Paatsalu core, western Estonia. - Proceedings of the Estonian Academy of Sciences, 55(2): 128-155.

Hints, O., Paris, F., Al-Hajri, S. (2015): Late Ordovician scolecodonts from the Qusaiba-1 core hole, central Saudi Arabia, and their paleogeographical affinities. - Review of Palaeobotany and Palynology, 212: 85-96. https://doi.org/10.1016/j.revpalbo.2014.08.013

Hints, O., Tonarová, P., Desrochers, A. (2016): Late Ordovician jaw-bearing polychaetes from Anticosti Island, eastern Canada, and their biogeographic significance. Canadian Journal of Earth Sciences, 53(7): 731-738. https://doi.org/10.1139/cjes-2015-0222

Jell, J. S., Talent, J. A. (1989). Australia: the most instructive sections. - In: Holland, C. H., Bassett, M. G. (eds), A Global Standard for the Silurian System. National Museum of Wales Geological Series, 9: 183-200.

Johnson, M. E. (1996): Stable cratonic sequences and a standard for Silurian eustasy. - In: Witzke, B. J., Ludvigson, G. A., Day, J. (eds), Paleozoic Sequence Stratigraphy: Views From the North American Craton. Geological Society of America Special Paper, 306: 203-211. https://doi.org/10.1130/0-8137-2306-X.203

Kielan-Jaworowska, Z. (1966): Polychaete jaw apparatuses from the Ordovician and Silurian of Poland and comparison with modern forms. - Palaeontologia Polonica, 16: $1-152$

Kraft, J. (1982): Dendroid graptolites of Llandoverian age from Hýskov near Beroun (Barrandian). - Sborník geologických věd, Paleontologie, 25: 83-95.

Kříž, J. (1975): Revision of the Lower Silurian stratigraphy in Central Bohemia. - Věstník Ústředního ústavu geologického, 50: 275-283.

Kříž, J. (1991): The Silurian of the Prague Basin (Bohemia) - tectonic, eustatic and volcanic controls on facies and faunal development. - In: Bassett, M. G., Lane, P. D., Edwards, D. (eds), The Murchison Symposium: Proceedings of an International Conference on The Silurian System. Special Papers in Palaeontology, 44: 179-203.

Loydell, D. K. (1998): Early Silurian sea-level changes. Geological Magazine, 135(4): 447-471. https://doi.org/10.1017/S0016756898008917

Loydell, D. K., Nestor, V., Männik, P. (2010): Integrated biostratigraphy of the lower Silurian of the Kolka-54 core, Latvia. - Geological Magazine, 147: 253-280. https://doi.org/10.1017/S0016756809990574

Männik, P. (2003): Distribution of Ordovician and Silurian conodonts. - In: Põldvere, A. (ed.), Ruhnu (500) drill core. Estonian Geological Sections, 5: 17-23.

Männik, P. (2008): Conodont dating of some Telychian (Silurian) sections in Estonia. - Estonian Journal of Earth Sciences, 57(3): 156-169. https://doi.org/10.3176/earth.2008.3.04

Männik, P., Loydell, D. K., Nestor, V., Nõlvak, J. (2015): Integrated Upper Ordovician-lower Silurian biostratigraphy of the Grötlingbo-1 core section, Sweden. - GFF, 137: 226-244. https://doi.org/10.1080/11035897.2015.1042032

Männik, P., Nestor, V. (2014): Stop B5: Panga cliff. - In: Bauert, H., Hints, O., Meidla, T., Männik, P. (eds), Ab- stracts and Field Guide, $4^{\text {th }}$ Annual Meeting of IGCP $591,10^{\text {th }}-19^{\text {th }}$ June 2014 , Estonia, University of Tartu, Tartu, pp. 185-187.

Muir, L. A., Botting, J. P., Carrera, M. G., Beresi, M. (2013): Cambrian, Ordovician and Silurian non-stromatoporoid Porifera. - In: Harper, A. T., Servais, T. (eds), Early Palaeozoic Biogeography and Palaeogeography. Memoirs, Geological Society, London, 38: 81-95.

https://doi.org/10.1144/M38.8

Murphy, M. A., Valenzuela-Ríos, J. I., Carls, P. (2004): On classification of Pridoli (Silurian) - Lochkovian (Devonian) Spathognathodontidae (conodonts). - University of California, Riverside Campus Museum Contribution, 6: 1-25.

Nestor, H., Einasto, R., Männik, P., Nestor, V. (2003): Correlation of some lower-middle Llandovery reference sections in central and southern Estonia and sedimentation cycles of lime muds. - Proceedings of the Estonian Academy of Sciences, Geology, 52: 3-27.

Nestor, V. (1994): Early Silurian chitinozoans of Estonia and North Latvia. - Estonian Academy Publishers, Tallinn, $163 \mathrm{pp}$.

Nestor, V. (2012): A summary and revision of the East Baltic Silurian chitinozoan biozonation. - Estonian Journal of Earth Sciences, 61(4): 242-260. https://doi.org/10.3176/earth.2012.4.05

Paluveer, L., Nestor, V., Hints, O. (2014): Chitinozoan diversity in the East Baltic Silurian: first results of a quantitative stratigraphic approach with CONOP. GFF, 136(1): 198-202. https://doi.org/10.1080/11035897.2013.873987

Rexroad, C. B. (1967). Stratigraphy and Conodont Paleontology of the Brassfield (Silurian) in the Cincinnati Arch Area. - Indiana Geological Survey Bulletin, B36: $1-64$.

Rhebergen, F., Botting., J. P. (2014): A New Silurian (Llandovery, Telychian) sponge assemblage from Gotland, Sweden. - Fossils and Strata, 60: 1-87. https://doi.org/10.1002/9781118906651.ch1

Šnajdr, M. (1978): The Llandoverian trilobites from Hýskov (Barrandian area). - Journal of Geological Sciences, Palaeontology, 21: 7-47.

Štorch, P. (1986): Ordovician-Silurian boundary in the Prague Basin (Barrandian area, Bohemia) - Sborník geologických věd, Geologie, 41: 69-103.

Štorch, P. (2001): Graptolites, stratigraphy and depositional settings of the middle Llandovery (Silurian) volcaniccarbonate facies at Hýskov (Barrandian area, Czech Republic). - Věstník Českého geologického ústavu, 76(1): 55-76.

Szaniawski, H. (1970): Jaw apparatuses of the Ordovician and Silurian polychaetes from the Mielnik borehole. Acta Palaeontologica Polonica, 15: 445-472.

Tonarová, P. (2008): Revision of Kettnerites ŽEBerA, 1935 (Scolecodonta, Silurian of the Barrandian area, Czech Republic): preliminary results. - Acta Musei Nationalis Pragae, Series B, Historia Naturalis, 64(2-4): 185-192.

Tonarová, P., Eriksson, M. E., Hints, O. (2012): A jawed polychaete fauna from the late Ludlow Kozlowskii event interval in the Prague Basin (Czech Republic). - Bulletin of Geosciences, 87(4): 713-732. https://doi.org/10.3140/bull.geosci.1317 
Tonarová, P., Hints, O., Eriksson, M. E. (2014): Impact of the Silurian Ireviken Event on polychaete faunas: new insights from the Viki drill core, western Estonia. - GFF, 136(1): 270-274.

https://doi.org/10.1080/11035897.2013.862855

Uyeno, T. T., Barnes, C. R. (1983): Conodonts of the Jupiter and Chicotte Formations (Lower Silurian), Anticosti Island, Quebec. - Geological Survey of Canada Bulletin, 355: 1-49.

https://doi.org/10.4095/109266

Verniers, J., Nestor, V., Paris, F., Dufka, P., Sutherland, S., Van Grootel, G. (1995): A global Chitinozoa biozona- tion for the Silurian. - Geological Magazine, 132(6): 651-666.

https://doi.org/10.1017/S0016756800018896

Wang, C.-Y., Aldridge, R. J. (2010): Silurian conodonts from the Yangtze Platform, South China. - Special Papers in Palaeontology, 83: 1-136.

Zhang, S., Barnes, C. R. (2002): A new Llandovery (Early Silurian) conodont biozonation and conodonts from the Becscie, Merrimack, and Gun River Formations, Anticosti Island, Québec. - Journal of Paleontology, 76(S57): $1-46$.

https://doi.org/10.1666/0022-3360(2002)76[1:ANLESC]2.0.CO;2 


\section{Explanations of plates}

\section{PLATE 1}

Selected scolecodonts from the Hýskov section

All specimens are in dorsal view, except for Figs 9, 28 and 29 which are in lateral view.

1.-5. Oenonites jennyensis ERIKSSON, 1997. 1. Apparatus, sample 2016-B; 2. Left MI, sample 2016-C; 3. Left MI, sample 2016-B; 4. Right MI, sample 2016-B; 5. Right MI, sample 2016-C.

6. Dubichaetaspis bergmani ERIKSSON, 1998. Right MI, sample 2016-C.

7. Oenonites spp. (aff. O. zappae). Right MI, sample 2016-C.

8. Incisiprion? sp. Right MI, sample $0 \mathrm{~cm}$.

9. Lunoprionella? sp. Sample 2016-A.

10., 13. Protarabellites staufferi? ERIKSSON, 2001. 10. Left MI, sample 2016-B; 13. Right MI, sample 2016-C.

11. Protarabellites staufferi ERIKSSON, 2001. Left MI, sample 2016-C.

12. Protarabellites triangularis ERIKSSON, 2001. Left MI, sample $75-80 \mathrm{~cm}$.

14.-16., 22. Atraktoprion sp. 14. Left MI, sample 2016-C; 15. MI left, sample $0 \mathrm{~cm}$; 16 . Right MI, sample 2016-C; 22. Right MI, sample 2016-C.

17. Vistulella kozlowskii Kielan-JaworowsKa, 1961. Left MI, sample 2016-C.

18. Mochtyella sp. Right MI, sample 2016-C.

19. Symmetroprion spatiosus (HINDE, 1882). Right MI, sample 2016-C.

20., 21. Kettnerites sp. 20. Right MI, sample $0 \mathrm{~cm}$; 21. Right MII, sample $0 \mathrm{~cm}$.

23., 24. Leptoprion sp. 23. Right MI, sample 2016-B; 24. Right MI, sample $130 \mathrm{~cm}$.

25. Mochtyellidae. Basal plate, sample 2016-B.

26. Pistoprion transitans Kielan-JaworowsKa, 1966. Left MI, sample 2016-C.

27. Pistoprion sp.?. Right MI, sample 2016-C.

28. Mochtyella sp. ex gr. trapezoidea KiElan-JawOrowsKa, 1966. Right MI, sample 2016-B.

29. Placognatha indet. Left MI, sample $0 \mathrm{~cm}$.

30., 31., 33.-35., 37. Xanioprion cf. borealis KIELAN-JAWOROWSKA, 1962. 30. Left MII, sample $0 \mathrm{~cm} ; 31$. Left MII, sample 2016-C; 33. Right MI, sample 2016-C; 34. Right MII, sample 2016-B; 35. Right MII, sample 2016-B; 37. Lateral teeth/basal plate, sample 2016-B.

32. Xanioprion? sp. Left MI, sample $0 \mathrm{~cm}$.

36. Tetraprion sp. Sample 2016-C.

Scale bar corresponds to $100 \mu \mathrm{m}$.

\section{PLATE 2}

Selected conodonts from the Hýskov section

1. Ozarkodina ex gr. oldhamensis REXroAD, 1967. Lateral view of Pa element, sample $190 \mathrm{~cm}$.

2., 11. Oulodus? sp. 2. Inner lateral view of $M$ element, sample $190 \mathrm{~cm} ; 11$. Posterior view of Sa element, sample 240-255 cm.

3., 5., 8., 9. Walliserodus sp. 3. Outer (3a) and inner (3b) lateral views of deboltiform element, sample $130 \mathrm{~cm}$; 5. Outer lateral view of asymmetrical dyscritiform element, sample 170-180 cm; 8. Outer (8a) and inner (8b) lateral views of unicostatiform element, sample $130 \mathrm{~cm}$; 9. Lateral views of symmetrical dyscritiform element, sample $190 \mathrm{~cm}$.

4. Pseudooneotodus aff. linguicornis JEPpsson, 2003. Upper view, sample $0 \mathrm{~cm}$.

6. Distomodus sp. Inner lateral view of M element, sample 40-50 cm.

7., 13. Panderodus equicostatus (RHODES, 1953). 7. Lateral view (furrowed face) of graciliform element, sample 2016-B; 13. Lateral view (furrowed face) of falciform element, sample 2016-C.

10. Decoriconus cf. fragilis (Branson et MeHL, 1933). Lateral view of acontiodontiform element, sample 2016-C.

12., 15. Rexroadus? sp. 12. Posterior view of Sb element, sample 2017-D; 15. Inner lateral view of Sc element, sample 2017-D.

14. Wurmiella cf. puskuensis (MäNNIK, 1994). Inner lateral view of $\mathrm{Pb}$ element, sample 2016-C.

16., 19. Dapsilodus sp. 16. Outer lateral view of acontiodiform element, sample 2017-D; 19. Outer lateral view of distacontiform element, sample 2017-D.

17. Ozarkodina aff. aldridgei Uyeno et BARnES, 1983. Lateral (17a) and lower (17b) views of Pa element, sample 2017-D.

18. Pseudooneotodus aff. beckmanni (BISCHOFF et SANNEMANN, 1958). Lateral view, sample 2017-D.

Scale bars correspond to $100 \mu \mathrm{m}$.

\section{PLATE 3}

Selected chitinozoans from the Hýskov section

1., 2. Bursachitina sp. Sample $0 \mathrm{~cm}$.

3.-6. Ancyrochitina spp. 3. Sample 2016-C; 4. Sample 2016-C; 5. Sample 2016-B; 6. Sample 2016-B.

7. Cyathochitina campanulaeformis EISENACK, 1931. Sample 2016-B.

8.-12. Cyathochitina cf. campanulaeformis EISENACK, 1931. 8. Sample 2016-B; 9. Sample 2016-A; 10. Sample 2016-B; 11. Sample 2016-C; 12. Sample $0 \mathrm{~cm}$.

13. Conochitina cf. iklaensis Nestor, 1980. Sample 240$255 \mathrm{~cm}$.

14. Conochitina cf. alargada CRAMER, 1967. Sample 260 $280 \mathrm{~cm}$.

15.-17. Conochitina spp. 15. Sample 260-280 cm; 16. ample 2016-A; 17. Sample 2016-C.

18. Conochitina cf. malleus (VAn Grootel, 1990). Sample 2016-C.

19., 20. Conochitina cf. emmastensis Nestor, 1982. 19. Sample 75-80 cm; 20. Sample $130 \mathrm{~cm}$.

21.-23. Conochitina cf. edjelensis elongata sensu Dufka 1992. 21. Sample $0 \mathrm{~cm} ; 22$. Sample 75-80 cm; 23. Sample 2016-B.

24.-27. Conochitina cf. edjelensis sensu Dufka 1992. 24. Sample 75-80 cm; 25. Sample 75-80 cm; 26. Sample 75-80 cm; 27. Sample 40-50 cm.

Scale bars correspond to $50 \mu \mathrm{m}$. 
PLATE 1

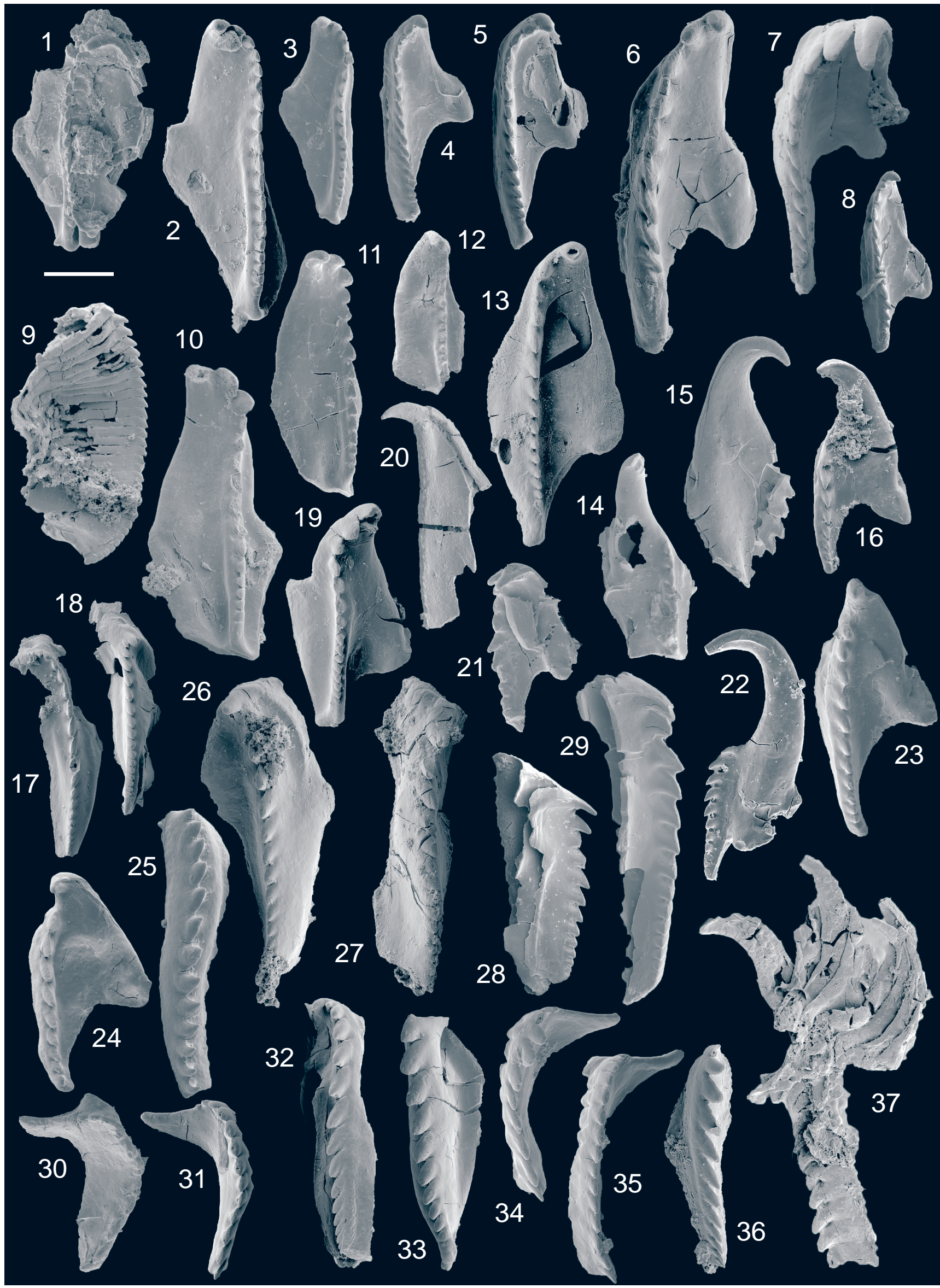


PLATE 2

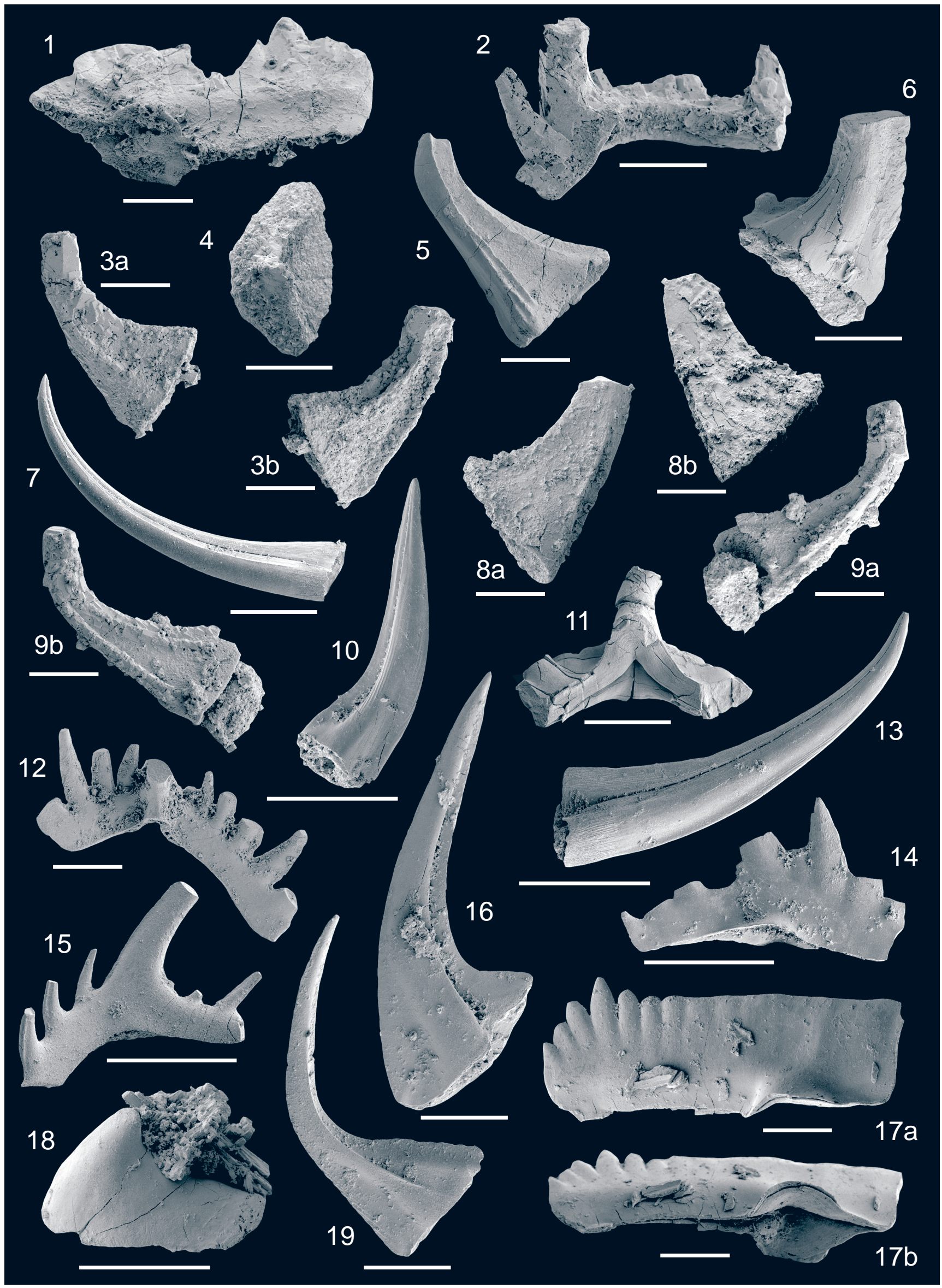


PLATE 3

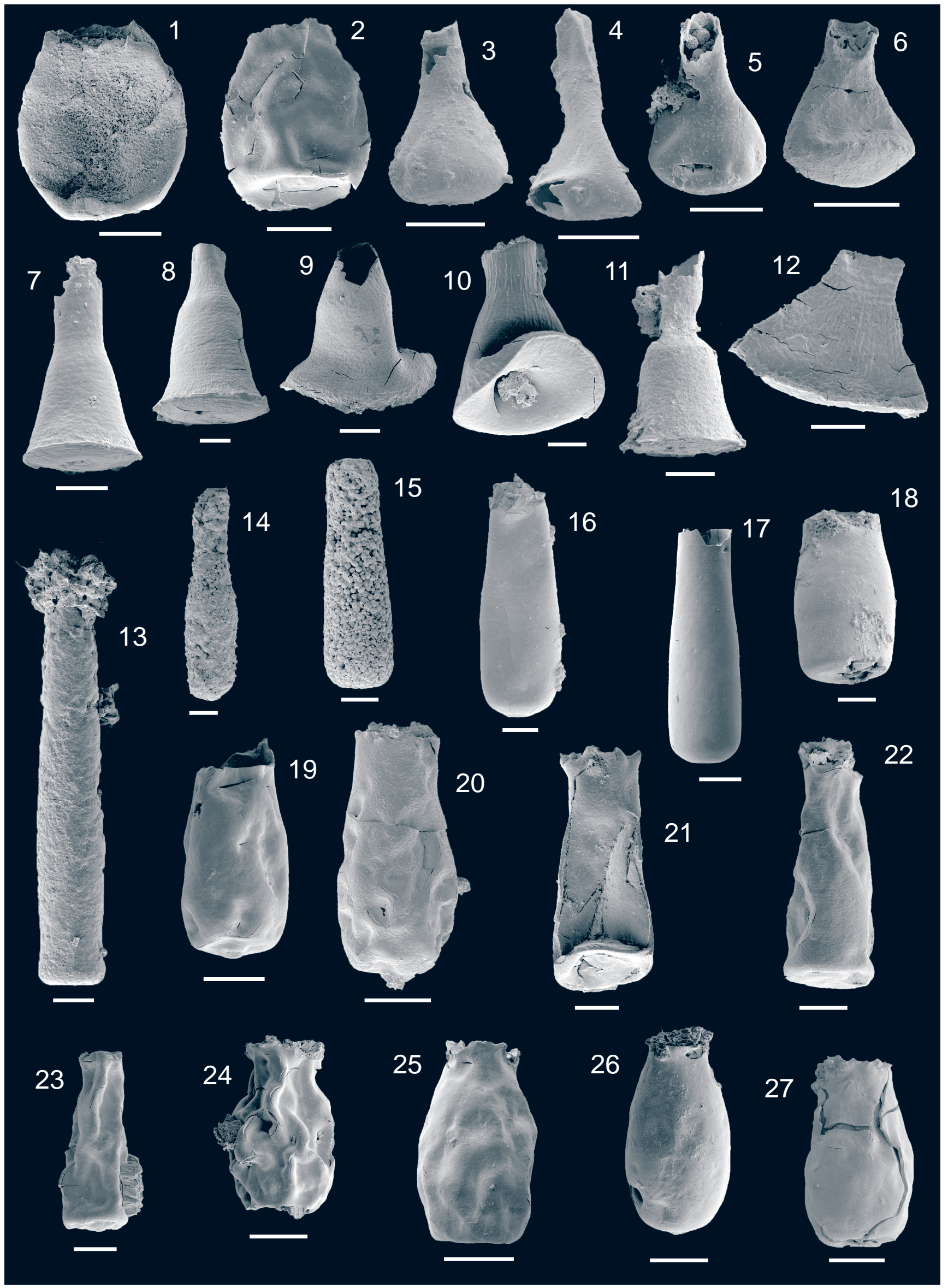

